\title{
Building vibrant school-community music collaborations: three case studies from Australia
}

\section{Brydie-Leigh Bartleet}

Queensland Conservatorium Griffith University, P.0. Box 3428, South Brisbane, QLD 4101, Australia

b.bartleet@griffith.edu.au

This paper explores the relationship between school music and community music in Australia. While many Australian schools and community music activities tend to exist in relative isolation from one another, a range of unique school-community collaborations can be found throughout the country. Drawing on insights from Sound Links, one of Australia's largest studies into community music, this paper explores three case studies of these unique school-community collaborations. These collaborations include a community-initiated collaboration, a school-initiated collaboration and a mutual collaboration. The author brings these collaborations to life for the reader through the words and experiences of their participants, and explores their structures, relationships, benefits, and educational and social outcomes. These descriptions feature important concepts, which could be transferred to a range of other cultural and educational settings in order to foster more vibrant school-community collaborations.

\section{Introduction}

Community music plays a significant role in many Australian settings, and millions of people participate on a weekly basis. While there have been numerous debates about what constitutes community music, it is widely acknowledged that it is a group activity where people join together to participate actively in the music-making process. It encompasses a wide and diverse range of musics, which reflect and enrich the cultural life of the participants and their broader community (see for example, Hawkins, 1993; Breen, 1994; Harrison, 1996; Cahill, 1998; Coffman, 2006). Over the past 20-30 years, a diversity of community music practices have grown in Australia and played a significant role in the wide and varied musical landscape of this country. As the Australia Council for the Arts describes:

The musical landscape in Australia today is broad and diverse, consisting of different cultural traditions, genres and practices. Increasingly, previously defined boundaries between musical genres are being crossed and exciting new genres are being created. Australia, with its multicultural make-up, is uniquely placed to lead the world in this development. The many interrelated layers that contribute to this musical landscape include grassroots music-making, music education, youth music practice, amateur music practice, moving through opportunities offered for professional development, to emerging artists, through community music practice and peak youth bodies, to 
professional artists and organisations creating and presenting music of the highest quality. (2001, p. 44)

Within the Australian context much of this community activity continues to remain somewhat disconnected from music programmes in schools, leaving the potential for vibrant school-community music collaborations yet to be fully realised (Temmerman, 2005).

\section{A background to the Sound Links study}

To learn more about the dynamics of community music in Australia and its potential synergy with music in schools, Queensland Conservatorium Research Centre Griffith University launched Sound Links, a two-year research project (2007-2008) in collaboration with partner organisations the Music Council of Australia, the Australian Music Association and the Australian Society for Music Education. The study had a number of aims, the most significant for this article being: to explore the current relationship between school music and community music in Australia, to articulate the benefits of building synergies between the two fields, and to examine how school-community collaborations could be further developed in the future.

To accommodate the aims of the research project, a combination of qualitative methodologies, including ethnographic case studies, and quantitative methodologies, including a nation-wide survey, were used. This article focuses specifically on the ethnographic case study findings, including insights from our field visits, semi-structured interviews, focus groups, participant and non-participant observations, and analyses of relevant documentation. These case studies were decided in consultation with the project partners, and chosen to represent a cross-section of Australian social contexts. These included Fairfield (NSW), Dandenong Ranges (VIC), Borroloola (NT), Inala/Acacia Ridge (QLD), McLaren Vale (SA), and Albany (WA) (Fig. 1).

This particular methodological approach lent itself well to uncovering the individual stories of the community musicians and educators, the dynamics of their practice, and the broader socio-cultural issues and structural frameworks that arise from these settings. As Higgins concurs 'ethnographic strategy and method unmask the traits of Community Music in action' (2006, p. 265, emphasis added). In order to fine tune our ethnographic approach and trial it in a local community music environment, a pilot study was also undertaken with the Queensland Youth Orchestras programme in Brisbane.

Because an ethnographic approach focuses on openness and reciprocal exchange, with its point of departure being the lived experiences of the researched, it was necessary for the research team to come face-to-face with the participants themselves. Full ethical clearance was given by Griffith University to undertake this research, and participants have given 'informed consent' for their identities and words to be used in resulting publications. This entailed the research team entering into a close interaction with the community musicians and educators in their everyday musical lives to better understand their beliefs, motivations and behaviours (see Tedlock, 2000, p. 455). In order to facilitate this, a large amount of forward planning was necessary. In each community I identified a key facilitator who had significant local knowledge and a wide network of contacts within the community. These key people introduced me to a number of community musicians, educators and groups, which not only made the organisation of the trips more efficient, given that we only had a 


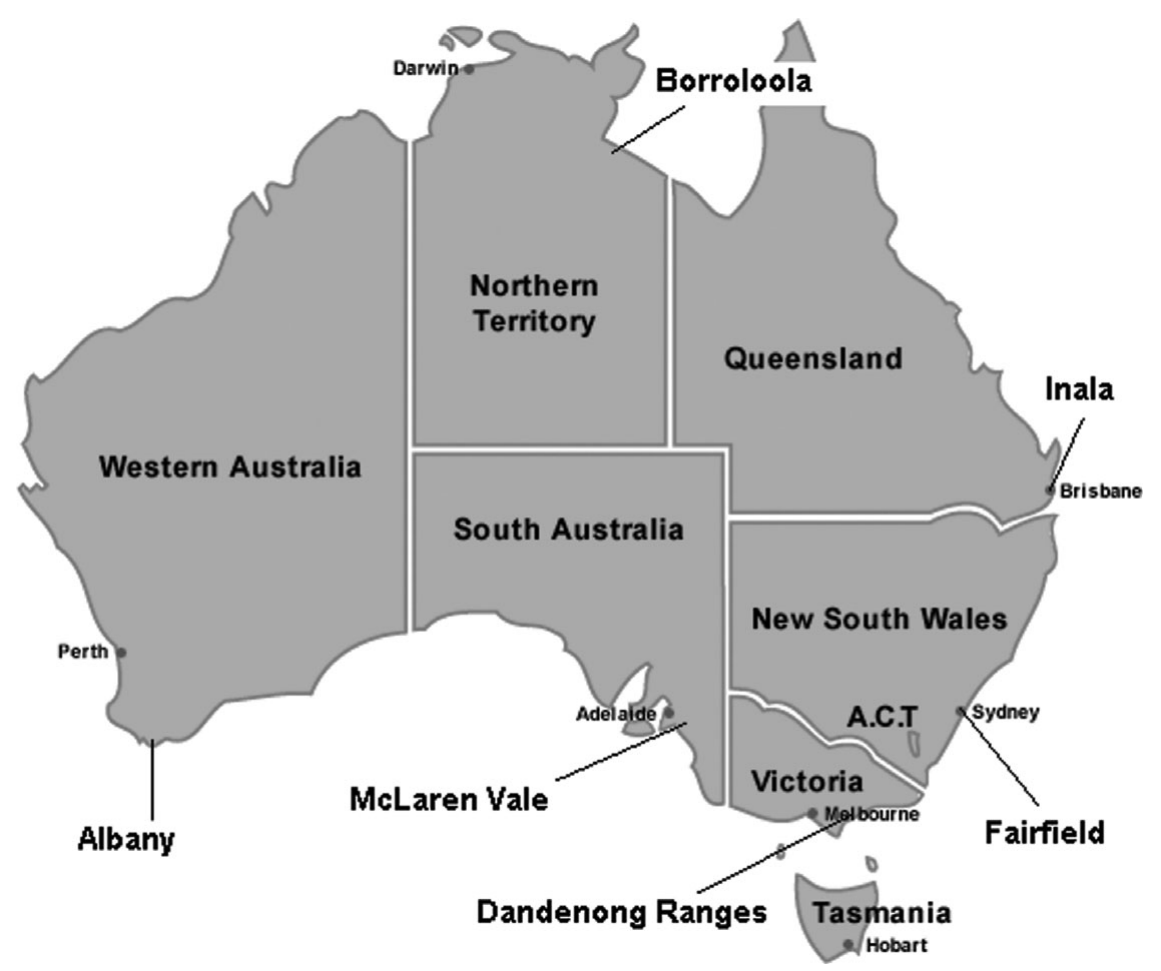

Fig. 1 Map of Australia with the musical communities involved in the Sound Links study

short amount of time in each setting, it also enabled me to tap into local knowledge and cover the community's activities in greater depth.

Each fieldwork trip was condensed into five days, and we conducted approximately 30 interviews or focus groups with 60-100 participants. In total, we interviewed and observed over 400 participants in these settings. These participants included primary school students, secondary school students, school music teachers, principals, parents, community music facilitators, community music participants, cultural development workers, youth workers, settlement workers, festival organisers, local council workers, instrument repairers, radio presenters and music retailers. As the focal point of each interview was the participant's individual stories, we used semi-structured interviewing techniques, where we had a list of questions we wanted to ask, but allowed the conversation to determine how the information was obtained. These questions were drawn from the research team's extensive experience in community music and education, issues raised in the online survey, ideas discussed at a Sound Links workshop run at the Australian Society for Music Education's national conference, and broader theoretical ideas identified in the literature.

We also attended rehearsals and performances in a variety of settings, such as community centres, schools, churches, sports fields, recording studios, farmers' markets, arts centres, galleries, teaching studios, hospitals, halls, clubs and temples. We visited local councils and community centres to gather documentation about the broader communities surrounding the music activities we were studying. The research also went beyond the more 
formalised interviews and observations; we shared many coffees, post-rehearsal drinks, as well as family meals with participants in some of the communities, particularly when I was travelling on my own. At times we were hauled into the action and handed various instruments to try out, other times we were told to sing along, and on two occasions I had to dance with the groups we were studying. All of these experiences led to new insights about the people involved, the broader communities and how music functions within these settings. As ethnography is a method that is about forming relationships, these interactions were obviously significant, but could never be exactly reproduced; as such, each community case study was subtly different (see Behar, 1999, p. 480). Likewise, the research team also differed slightly from trip to trip. I attended each fieldwork visit to ensure a consistency of approach; however, sometimes I was on my own, other times I was accompanied by different team members, and these changes in personnel subtly influenced the dynamics of our interactions with the community musicians.

The online survey was designed to validate these ethnographic case study findings and benchmark them against national impressions and perceptions. The survey was developed in consultation with the partner organisations, and distributed to a wide-range of music educators, community music facilitators and practitioners, music therapists and arts administrators, mostly through their mailing lists. Over 200 people responded, representing every state and territory. While a wide range of practitioners working across many different styles and cultural traditions responded to the survey, school teachers made up the highest proportion of respondents $(60.3 \%)$ and a large proportion of those respondents were involved in choral music $(48.6 \%)$ at the time of responding.

The analysis phase involved identifying a number of key themes and coding and sorting the data from the ethnographic case studies and the online survey into categories. Given the fact that each of the six case studies and online survey respondents represented very different sets of circumstances and environments, many of the characteristics of the community music activities explored were unique to their specific participants, facilitators, sites, contexts, aims and infrastructure. However, there were also strongly shared underlying characteristics between the activities. During the analysis phase, it also became clear that nine domains were present (in varying degrees) in all the community music activities observed, and indeed in the research team's recollections of similar projects across the world. These domains included: Infrastructure; Organisation; Visibility and public relations; Relationship to place; Social engagement; Support and networking; Dynamic musicmaking; Engaging pedagogy and facilitation; and Links to school (see Appendix 1). The final domain - Links to school - forms the focus of this article. The process of analysing and then writing about these domains has called for a balance between the individual participants' stories, the research team's personal observations and a broader social critique. The resulting final report paints a vivid picture of musical activity in Australia, and outlines a number of targeted recommendations for creating a sustainable environment for community music and school music in this country (see Bartleet et al. 2009).

\section{The relationship between school music and community music in Australia and beyond}

As we travelled between the six case-study locations conducting fieldwork in schools, music classrooms, community centres, sporting fields, places of worship and a range of 
other settings, we came to the realisation that many Australian schools and community music activities exist in relative isolation from one another. This observation is substantiated by the findings of our online survey (see Bartleet et al., 2009). When we asked our respondents whether their school-community collaborations are reaching their full potential, over $74.3 \%$ said ' $\mathrm{No}^{\prime}$. According to our respondents, a number of significant issues appear to be hindering these potential collaborations, such as restrictive school timetables, and a lack of resources including funding, venues and volunteers. Our respondents also suggested that some Australian schools appear to place less value on community music-making as a site of music education, and refuse to formally acknowledge the plethora of musical activities their students undertake outside the school curriculum.

Our Sound Links findings echo those of Temmerman's (2005, p. 113) in an article on connecting children's cultural contexts, when she describes the problematic disconnections that commonly occur between young Australian people's music-making at school, at home and in the community. The Australia Council also recognises this issue, suggesting that the formal education system is only one means of influencing the attitudes of children and that it cannot be expected to bring about significant change in isolation' (Saatchi \& Saatchi, 2000, p. 90). Recognition of this did reach the general brief of the recent National Review of School Music Education in Australia, which acknowledges that 'communities play a vital role in effective music education' (Department of Education, Science \& Training, 2005, p. vii); however, the final report still primarily focuses on music in schools, leaving a number of questions and issues relating to these school-community connections unanswered.

A similar situation is observed by Carruthers (2005) in the North American context, where he suggests 'although fluidity between communities and schools seems ideal for both constituencies, this does not always occur' (p. 3). Price (2002) offers similar observations from the UK context:

The relationship between community musicians and formal education continues to cause concern, though for rather different reasons. Many musicians now rely upon schools-based work for a significant portion of their employment, and have become accustomed to the constraints of working in that environment. But it seems to me that a genuine sharing of skills (the curricular and pedagogic skills of the classroom teacher, and the creative and often inspiring approaches of good community music approaches) is as remote as ever. (p. 4)

Despite the prevalence of these disconnections, during our Sound Links fieldwork, we did still discover a range of vibrant school-community collaborations around the country. We came to the realisation that such joint ventures provide deeply enriching musical, social, cultural and pedagogical experiences for their participants, and oftentimes present practical solutions to the resourcing and infrastructure challenges facing many school and community music programmes. Such observations are echoed in the literature on community music and music education more broadly. Speaking from a Canadian context, Veblen (2003) observes 'there is a rich and complex mosaic of community music groups, activities, and networks in Canada which relates to music in schools in important ways' (Veblen, 2003, p. 27). Likewise Robinson (1998) describes the ways in which groups of arts organisations, schools and colleges in the USA have joined together in innovative working relationships to challenge the 'hows, whats, and whys of the music education enterprise in both institutions' (p. 36). Albrecht (1997) similarly explores how the expansion of parental,

\section{CAMBRIDGE JDURNALS}


teacher and community resident participation in the culture of Wisconsin public schools has resulted in positive social changes in these communities. From a different cultural perspective, Hebert (2005) examines the ways in which Japanese school bands are fostering a symbiotic partnership between schools, communities and industry.

To explore the different ways in which Australian schools and communities have worked cooperatively together to address these aforementioned issues, I now turn to three case studies from the Sound Links study. These case studies span three diverse socioeconomic and cultural contexts, and demonstrate three different models of collaboration, including a community-initiated collaboration, a school-initiated collaboration and a mutual collaboration. In line with the ethnographic methodology outlined above, in the following sections I bring these school-community collaborations to life for the reader through short ethnographic narratives. These narratives have been carefully constructed from interview transcripts, observations and fieldwork notes and paint a picture of the fieldwork contexts, characters, music-making, topics of discussion and broader lessons learned (for the construction of such narratives, see Behar, 1996; Amit, 2000; Cottrell, 2004; Ellis, 2004). These narratives explore how these collaborations are structured, how they are underpinned by the significant relationships between those involved, and the benefits and educational and social outcomes of such ventures.

\section{Case study one: a community-initiated collaboration (Stylin' UP Festival and local schools in Inala, Queensland)}

As I exit the main road and follow the signs to the Murri School, I notice the large industrial blocks and modest housing lining the roads. This urban context, known for its high Indigenous population, is one of the case studies in the Sound Links project. ${ }^{1}$ As I sign in at the school office, the distant sounds of children's voices drift in. While I wait for the lady behind the desk to finish her phone call I notice the faint vibrations of hiphop beats coming through the timber floorboards. She finishes her phone call and looks at me. 'I'm here to watch the Stylin' UP workshop. I'm from the Sound Links project', I explain. 'Robert Cobb is expecting me.' She slides the glasses off her nose. 'No worries', she smiles. 'I'Il call Uncle Robert for you.' As I wait for Robert I look around the office at the brightly coloured posters on the walls about Indigenous pride and the importance of healthy eating. The hip-hop beats continue and I hear the muffled sound of young men's voices rapping into microphones. This is a unique school. It's an Aboriginal and Islander Independent Community School (years K-12), and one of a handful of local schools participating in the Stylin' UP programme. Stylin' UP is an Indigenous-owned hiphop and $\mathrm{R}^{\prime} \mathrm{n}^{\prime} \mathrm{B}$ skills development programme run by the local community, schools and the Brisbane City Council for young people in Brisbane's southwest corridor. Robert is the teacher who helps organise the Stylin' UP workshops at the Murri School. When he finally arrives he towers over me as he warmly shakes my hand, 'G'day Brydie, I'm Robert.'

As we walk towards the workshop room Robert explains how Stylin' UP originally developed in 2000. It was the result of the local community and the Brisbane City Council coming together to try and increase young Indigenous people's engagement in the arts and their culture. He proudly tells me they are expecting an audience of over 10,000 this year. The hip-hop beats get louder as we near the workshop room. Robert smiles before 
speaking, 'They're practising for the festival in a few weeks. All these workshops culminate in a big festival day in May every year.' As we wait outside for an appropriate moment to enter, I notice the brightly coloured Stylin' UP poster on the pinboard outside. Seeing my interest, Robert explains these workshops don't only focus on music, but other creative arts such as graphic design, dance, events management and video production. 'Local schools and community centres provide the facilities for all these workshops to happen', Robert adds.

When there is a brief moment of silence we enter the room. Three teenage men, casually dressed in their school uniform, are standing in the centre with microphones discussing what they've just finished. A community music facilitator, Luke O'Sullivan, is sitting at a laptop manipulating the beats. I immediately notice the impressive electronic equipment he has. Later I find out his equipment is worth over $\$ 20,000$, and no doubt a draw-card for enticing students to participate. The group decide to start a new song and all of a sudden the room is filled with loud beats and rapping again. As I sit quietly at the side of the room, I observe Luke's pedagogical approach. He clearly views the young people as active participants and collaborators and allows them to be very hands-on. He seems to masterfully strike the delicate balance between achieving good quality artistic outcomes (which are crucially important in terms of motivating young people and giving them a sense of pride in what they do) and looking after the needs of the young men in his care. I am also intrigued by the way the young men assist one another - with lyrics, music production ideas and stagecraft - and essentially support one another's development. Their nodding heads, moving bodies, grunts and verbal assurances offer critical peer feedback and encouragement to each other. I can see that they want their music to be good, it has to tell the story of their experiences and they want to be proud of it.

After a while Robert introduces me to Kelvin Lui, one of the Indigenous Elders who comes along to oversee these workshops. Kelvin suggests we step outside so we can chat. We find a bench outside the room and as we sit down Kelvin explains that some locals originally questioned whether hip-hop was the most appropriate genre for this programme, particularly because of its heavy American influences and associations with violence, machismo and misogyny. However, as he goes on to explain, many have come to acknowledge that this genre gives the young Indigenous people of this area a voice to express their sense of cultural identity and experiences. 'Contemporary music, I think, appeals more to the younger generation of today', Kelvin suggests. 'It's a very effective tool that is used to get the message, a positive message out to young people to empower and encourage them' (Kelvin Lui, personal interview, 22 May 2008).

A day later my colleague Huib Schippers and I visit another local school, Glenala High School, where the student population is somewhat different from the Murri School. As we enter the school grounds we notice a large mural on one of the buildings saying 'Glenala: Strong in Spirit; Strong in Culture; Strong in Identity' with faces representing not only Indigenous cultures, but a range of Pacific Island groups. When we speak to Christine Hayward, Head of Performing Arts, she describes the benefits of the Stylin' UP programme and the success it has had in reengaging some of their students in the learning process. However, she also speaks frankly about some of the tensions Stylin' UP has engendered in her school. According to Christine, Glenala High School has worked very hard to create a sense of harmony between its different cultural groups, particularly the large Pacific 
Islander and Indigenous populations. She believes that singling out the Indigenous students somewhat counteracts the school's efforts in creating a sense of cultural harmony:

Here our philosophy is integration, you know. We've got a lot of cultures and I don't like separating kids off for that reason when we've tried to work for so many years in harmony ... Back in the early days there was a lot of disharmony with the Polynesian students and the Indigenous students, and we worked really hard to try and get them together. So it goes against our grain in some respects, you know segregating kids off. (Christine Hayward, personal interview, 23 May 2008)

When we later raised these concerns with the council organizers of the programme, they were quick to point out that while it is an Indigenous-specific event, it is still very multicultural with many different cultural groups participating in the festival day in May, and the workshops are not restricted to Indigenous young people. As I think back to the workshops I observed, I did notice a large number of young Pacific Islander people participating.

Despite the tensions that arise from this being an Indigenous-specific programme, a number of local community members spoke about the importance of this focus. Given that substance abuse is prevalent amongst youth in this urban context, and there have been a handful of youth suicides in recent years, community members spoke about the need to give young people a creative vehicle to speak about these experiences, and also positively express their sense of cultural identity. As Chelsea Bond, a local Indigenous woman who serves on the Stylin' UP community crew, explained,

The one thing that's great about Stylin' UP is that it is an example of where we can feel really proud of our community, of our young people. They're not just criminals. They're not just a group with immense social problems; they're actually resourceful, resilient, inspiring people that we can all learn from. So it puts young people up in front, which I think is really good. But it recognises that our identity as Indigenous people is not just grounded in this idea of the exotic Other and that we all have to be in lap-laps and traditional dance. We've still retained our culture but we're articulating it in different ways ... Stylin' UP is our corroboree for today and that's what I think has pulled people in over the years and attracted people to it, is that it's imagined us very differently to how we're frequently talked about. (Chelsea Bond, personal interview, 16 June 2008)

Chelsea went on to explain that the reason why Stylin' UP has been so successful in achieving this is because it has the support of the local Indigenous community. In fact, a year-long consultation occurs with the community crew - comprising local Elders, youth organisations, school representatives, community organisations, businesses and other relevant and interested parties - and leads to a strong community involvement and sense of ownership over the programme. This, she believes, is why it has grown from strength to strength over the years it has been running.

As this brief window into Stylin' UP has shown, such a community-initiated collaboration has the potential to re-engage students in the learning process, who may have become disconnected from the mainstream schooling system. As Dreeszen et al. (1999) have similarly observed, such collaborations can help 'mitigate social problems including drug abuse, violence, teenage pregnancy, poverty, and lack of community pride. Arts and 
education partnerships enable young learners to reflect upon and represent themselves in their own communities, to become active citizens in their own neighbourhoods' (pp. 3-4). This engagement in the Stylin' UP programme has allowed school students to find a way to communicate about their life experiences and express a sense of pride in their cultural identity. Such observations are echoed by Mitchell (2006) when he explains,

As an educational format, a vehicle to express anger at discrimination and marginalisation and pride in one's heritage, a way of binding communities together through dance and performance, a declamatory form of storytelling set to music, and above all a means of expressing oral history, hip-hop's affinities with Aboriginal cultural forms make it an ideal means for youth to get in touch with their tribal identity, history and cultural background. (2006, p. 136)

\section{Case study two: a school-initiated collaboration (Tatachilla Lutheran College, South Australia)}

As my colleague Peter Dunbar-Hall and I drive down the gravel road towards Tatachilla Lutheran College in McLaren Vale, the last rays of sunlight begin to fade behind the rows of adjoining vineyards. This rural wine-growing region is one of the case studies in the Sound Links project, and the years $\mathrm{K}-12$ school Tatachilla is one of the primary locations in our fieldwork. ${ }^{2}$ As we enter the school's Performing Arts Complex we are greeted with a cacophony of sounds. We begin to walk down the hallway looking for Greg John, musical director of the community carols concert and Head of Performing Arts at the college. In one room we pass the men's choir singing carols, in another the children's choir practising their moves to Rudolph the Red Nosed Reindeer, and at the end of the corridor we see ballet dancers rehearsing their Nutcracker pirouettes. The rest of the school is dark and deserted, but every room in the Performing Arts Complex is buzzing with activity. 'Do you know where Greg is?' I ask a passing violinist. She points to the large rehearsal room in the centre of the building. We quietly slip into the room and notice Greg on the podium. He hands the baton over to his assistant, Mark DeLaine, and comes over for a chat. 'So here you have it', he says with his arms open wide, 'our orchestra of community members!' Peter and I smile at his enthusiasm. 'In term 4 every year, the school and community come together to put on this major community carols concert. It's pretty big, isn't it?' In fact, the production involves a large number of community organisations, community musicians and other local schools (particularly in the children's choir), and draws a crowd of 2,000 people every year. I scan the large ensemble noticing the wide age range in the players from primary schoolers to retirees. Many of the musicians are wearing Christmas hats and have decorated their stands and instruments in tinsel. As if reading my mind, Greg chimes in, 'see the viola section? Our youngest player is 13 and our oldest player is 87 . The philosophy', Greg adds, 'is that all musicians should be encouraged to have a go.'

As the rehearsal gets underway, I observe very standard pedagogical and rehearsal methods at play. While the sound of the ensemble is fairly average in quality and the conductors do not seem to be doing anything out of the ordinary, what is extraordinary is the level of engagement shown by the ensemble. At the evening tea break, Peter and I sit down to interview a group of them and ask them about this. They avidly speak about how well structured the preparation for this event is, and how well supported they feel in their

\section{CAMBRIDGE JDURNALS}


musical development. The adults in the group explain that these things are necessary for them to develop their musical skills at this stage in their lives. They also speak about the shared values of this ensemble and the non-judgemental leadership shown by the directors. Such factors, they believe, contribute towards an immensely satisfying social and musical experience. As Joanne Weller explains,

The reason why I've done it is to switch off from my work ... I go home and my husband says to me, 'You look a different colour.' [Everyone laughs] 'You actually look alive again.' Because I'm a bank manager with ANZ and the bank takes my life, I'm basically married to my job and to commit two hours a week to come along and do this has just been magnificent. And to just play again, is just beautiful. (Joanne Weller, community orchestra, focus group interview, 5 December 2007)

We soon discover that many people in the local area see Tatachilla Lutheran College as one of the main hubs of community music activities in this region. In addition to the community carols concert, the school also stages regular musical productions, which parents, grandparents and siblings of school children are encouraged to become involved in, either through performance or production. For these events the school provides a venue, musical expertise, performance occasions, and opportunities for participation. When we speak to the school principal, Colin Minke, about the benefits of these school-community collaborations he explains,

There has been a huge diversity [of activities] which has been part of the reason I think the success has happened not just in the performing arts and music, but in environmental areas ... It's just that whole package about how a school brings a community in and how the school can go out into the community. (Colin Minke, personal interview, 5 December 2007)

As Colin goes on to suggest, there are many benefits to this two-way partnership for the school, local community and participating families. Such assertions are echoed in the literature by Dreeszen et al. (1999) when they suggest that the arts are one of the most powerful means for forging bonds between parents, schools, and communities ... Partnerships significantly expand the opportunities for these important, family-based learning experiences both inside and outside the school buildings' (pp. 3-4).

Given how strong the links between the school and community are, at times we found it difficult to separate school-based music from community-based music activity. We discovered that in some events, performers simultaneously belonged to the school and to community groups. In other cases, community groups had commenced under the umbrella of school events and had subsequently branched out on their own. For example, the inclusion of parents as performers in school stage productions had resulted in a women's and a men's choral group of parents who wanted to continue choral activity after the stage productions were over. These two groups were ongoing, and had developed their own performance opportunities independent of the school through which they had been developed. During our subsequent interviews with members of these groups, they commented on how they had been empowered by Greg, the music teacher at the school, and how he had encouraged them to devise their own ways of managing performances and 
rehearsals; the development of these skills was seen by them as necessary and positive to run community music activity, skills in arts management were needed.

When we interview Greg and Chris Majoros, the producer of the Community Carols and a music teacher at another local school, a couple of days later we relay this positive feedback. They seem genuinely pleased. I then ask them both, 'What is it that makes this production so successful?' There is a moment of silence as they both contemplate the answer. Greg looks me straight in the eye and says 'Key people, who are passionate, energetic, and skilful.' Chris chimes in, 'That was going to be my answer as well!' 'Key people', I clarify. 'Yes, and also people who know the area', Gregg nods his head, 'and they never count the hours, because unless somebody's doing that, it would fall in a heap' (Greg John and Chris Majoros, personal interview, 7 December 2007). Such a situation is not without its challenges, as Greg's comment suggests. Such productions often fall on the shoulders of already busy teachers like Greg and Chris, and are physically and emotionally taxing on themselves and their families. While the school is highly supportive of such community collaborations and very generous in the provision of its facilities, tuition and resources, without the efforts of key individual teachers productions such as this simply would not happen. However, despite such demands, these teachers seem to have a genuine belief in the power of music to bring their schools and communities together in positive ways. This was clearly evident in our last conversation with Greg when he explained,

It's about community building and relationship building and the underpinning thing in all of this is ... the music.... From the stiff accountant through to the hippy performing together, from an 87-year-old to a 13-year-old, and the little kids and the mums and dads performing with each other ... all of [this] is only possible because of the music. I don't know any other medium that could do it. (Greg John, personal interview,

9 December 2007)

As this brief window into the community carols event has shown, there are many benefits to such school-initiated collaborations both for the school and the broader community. These benefits include significant intergenerational learning opportunities, the sharing of resources and a positive public image for both community music-making and the school within this region. These benefits strongly resonate with Carruthers' (2005) observations when he suggests: 'Non-curricular activities fertilize school music programs and curricular programs yield non-curricular activities. Whatever the structural paradigm might be, successful activities and programs accrue reciprocal benefits to communities and schools' (p. 2).

\section{Case study three: a mutual collaboration (Dandenong Ranges Music Council and Upwey High School, Victoria)}

As I drive along the mountainous road towards the Dandenong Ranges Music Council (DRMC) I take note of the lush vegetation and quaint houses along the way. Turning into the driveway of the local high school I immediately notice a sign saying 'Dandenong Ranges Music Council' with an arrow pointing left to the 'Community Music Centre'. The DRMC is located on the grounds of Upwey High School, and is one of the case studies in the Sound Links project. ${ }^{3}$ As I walk inside the Music Centre I notice the brightly coloured wall

\section{CAMBridge JUURNALS}


hangings, posters, papier-mâché masks, certificates, trophies, and framed photographs of music performances and productions. Karen Noonan, one of the administrators and music teachers at a local primary school, greets me. 'It's cold outside, isn't it?' I agree, wishing I'd packed something warmer to wear. 'Can I make you a cup of tea?' she offers. I gratefully accept, and follow her into the adjoining kitchen. 'Bev will be here tomorrow', she explains. 'She wanted to be here to welcome you, but she had some family things to do.' 'That's

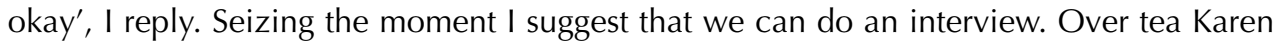
explains that she volunteers at the DRMC one day a week and has a busy instrumental teaching schedule for the rest of the week. She is also a volunteer fire fighter and seems to belong to a long list of community organisations. This kind of community involvement is typical in the Dandenong Ranges, she tells me.

Karen explains how the DRMC was formed by Bev and a group of people in 1979 to bring music to the community. It originally started in Bev's garage, but is now located on the school grounds. Karen explains that the Music Centre building was originally the school's cafeteria and after it was badly damaged in a fire, Bev seized the opportunity and repaired and refurbished it into a Music Centre with funding from the Ministry for the Arts and Education, the Shires of Lilydale and Sherbrooke and the Potter Foundation. Karen proudly tells me that the DRMC is now considered to be a model for community music organisations throughout Australia. She describes how it provides learning and performance opportunities for local musicians of all ages and abilities, and quite a few members have gone on to become professional performing musicians, teachers or stage management professionals. When I ask about staffing, Karen explains that for the weekly programmes they employ a number of local composers, teachers, music therapists and administration officers. For the major projects they often bring in outside music and stage management experts to assist.

As we're finishing our interview, Carm Hogan, the singing teacher, quietly walks into the room. 'Morning', she chimes. She begins to set up her gear. In a matter of minutes we hear the doors open and four noisy teenage girls enter the room. They are here for their singing lesson. This is the beginning of a constant stream of school students who come to the DRMC for community music classes throughout the day. At the end of the school day, individual after-school classes are conducted before the evening's rehearsals begin. Tonight it is the young strings group, tomorrow it is the orchestra, the night after the jazz group and the night after that the Hilltop Singers choral group. On certain days music therapy sessions and early childhood music programmes are also run, and travelling singing groups from the DRMC visit aged-care facilities to perform. I attend most of these activities and while they represent fairly traditional approaches to pedagogy and ensemble facilitation, I am once again struck by the high level of engagement fostered by these groups.

When Bev eventually arrives the next day, there's a reprieve in the morning's activities, so she and I sit in the rehearsal room with a cup of tea. Bev tells me that despite all her years of service to the DRMC, she is not a musician but a midwife by trade. We chat about the philosophy of the DRMC and she explains,

The philosophy I think is about creating the opportunity for people of all ages and abilities to make music; and for music to be performed and integrated into the lifestyle of the community. And then the other part of that is in partnership with the local music 
teachers and schools and the professionals that actually live here so that we create work for them. (Bev McAlister, personal interview, 14 September 2007)

She proudly describes the way every ensemble or project run by the DRMC has developed 'organically' through close community consultation, and how this has ensured a high degree of social engagement and strong sense of community ownership. However, as Bev cautions, 'sustainability of these groups is very important to us'. To achieve this, the DRMC encourages their various groups to become both artistically and financially independent. As a result, many of the ensembles that first started through the DRMC have become incorporated and are now functioning successfully as independent community organisations. As the next group of school students come rushing through the doors for their didgeridoo lessons, Bev quickly points out that these weekly programmes are only part of what they do. The DRMC also runs major productions with local schools and the broader community. 'Don't let me forget to tell you about our Hillsongs productions', she says over the loud voices of the students. 'Later today', she suggests, 'I'Il take you for a drive out to Monbulk Primary School so you can meet some of the kids who were involved.'

As we're driving through the small tree-lined roads towards Monbulk Primary School Bev tells me about the Hillsongs performances, which bring together community ensembles and students from all the local schools. In the lead up to these performances, mass workshops and rehearsals are coordinated by appointed music directors, local teachers and professional stage directors. These projects specifically focus on issues that have significant local interest and deep connections to this place. The DRMC also runs other projects, such the Composers Connecting Community programme, which Bev tells me involved over 400 schoolchildren in 2006. The workshops and performance focused on the work of C. J. Dennis, an acclaimed Australian poet who lived in the Dandenong Ranges, set to music by local composer Dr Calvin Bowman. Bowman wrote a Suite consisting of seven songs based on text from C. J. Dennis' A Book for Kids. The project gave students and community members the opportunity to work with a 'living composer' and gave them insights into the compositional process. Additionally, the project reintroduced the works of C. J. Dennis to a new generation of readers. Bev tells me that some teachers from local schools also integrated this project into their classroom music curriculum.

When we arrive at Monbulk Primary we are warmly greeted by Ray Yates, the principal of the school. He ushers us into a quaint staff room, where a fireplace is burning. A group of six students file in, and perch closely together on a bench at the side of the room. They avidly describe all the DRMC activities they've been involved with. Remembering our earlier discussion about the Hillsongs project I decide to ask them about it. For them the highlight was working with the featured ensemble, Vox Congo, a group of local African musicians. 'So what did you learn from doing this that you wouldn't normally learn if you were just doing choir at school?' I ask. One of the young girls puts her hand up and I gesture at her to speak. 'That the music in Africa is really jazzy and 'beaty' and it's really good for dance. Yeah, it has a good catchy tune to it.' The others agree, 'What else did you learn?' I prod. This time a young boy answers, 'Their cultural music, how African people do their music. Because we're all used to our sort of music, like ABBA and all that sort of stuff.' I smirk at the ABBA reference. 'And then we see the African guys', he

\section{CAMBRIDGE JDURNALS}


continues, 'and they're just so much different. But I would rather go and do African sort of things. And the way they dress is also colourful and reflects the ways they dance. And they wear make-up on their faces like face-paint when they dance. And when they dance they've got so much energy.' They nod their heads and then wait for me to ask another question. 'So how important is it to have projects where you get to be exposed to another culture that you wouldn't normally encounter on a daily basis?' I ask. 'It's important', a young girl says, 'because you actually get to find out what they really dance like. If we just stayed at school and stuff we wouldn't be able to find that out. Yeah. We learnt something new, which is from another country. I think that's really important, that we learn about other cultures, not just ours' (Monbulk Primary, focus group interview, 14 September 2007). On the drive home Bev and I marvel at the profundity of what these young students have said to us, and the cultural learning opportunities this programme has provided them with.

After watching the way in which the DRMC operates, I've come to realise this is not simply a community-initiated or school-initiated collaboration, but rather a mutual collaboration that requires an equal partnership between those involved. When I interviewed Greg Holman, the principal of Upwey High School, he reiterated this,

You have to see it as a two-way thing and you have to make sure you put in your part of that too ... You know the partnership here is very strong because we've seen the benefit that we can gain from it and the input we can have in it. The people who are involved are generally interested in how they can better provide for music in schools not only for their own program ... but also in schools in general ... We see it as another resource for teaching staff to use that provides music education that wouldn't be available to some students. From a provisional point of view it's a very important educational organisation because not all schools can provide music education. (Greg Holman, personal interview, 11 September 2007)

In our discussion Greg went on to suggest that the benefits of building such partnerships are wide ranging; from an improvement to the school's curricula and the quality of learning, to other factors, such as the active involvement of parents and families in student learning, the professional development of teachers, community leaders and musicians.

As this brief window into the DRMC has shown, such a mutual collaboration has the potential to result in opportunities for the community and school students to perform together in weekly and flagship activities, as well as a well-connected community where local organisations can work hand-in-hand to address a range of local issues of interest. These exchanges can result in a pooling of resources, an enriching musical experience for the participants, and a significant community building exercise for all involved. As Dreeszen et al. (1999) suggest, 'Partnerships between school systems and community arts partners are effective ingredients of school improvement strategies. They increase community awareness of educational issues and mobilize community resources in the service of school improvement' (pp. 3-4). Such collaborations can thus provide school music programmes with a wide range of learning experiences outside those offered in the formal curriculum. 


\section{Conclusions}

Given the current disconnections which appear to be occurring between school music and community music in Australia, these three case studies represent somewhat unique situations which are not commonplace within most communities. Having said this, they do provide inspiring and informative exemplars for other schools and communities wanting to foster such relationships in the future. As the Stylin' UP, Tatachilla Lutheran College and DRMC and Upwey High School case studies have shown, despite the investments of time and resources required to run these programmes, they can lead to important musical, social, cultural and pedagogical outcomes. These include the engagement of young people in the learning process, as well as significant intergenerational learning and performance opportunities. Through the sharing of learning resources, personnel and facilities these collaborations also result in a well-connected community where community organisations, schools and local councils work hand-in-hand to address issues of local concern. This shared process can lead to a positive public image for both community music-making and schools within a region.

For these outcomes to be achieved, a number of common elements need to be in place. As the three case studies in this paper suggest, these elements revolve around people, programmes, facilities, resources and the broader community. The collaborations require highly motivated, dedicated and well-respected personnel, often in the form of local school teachers and community music facilitators. Likewise, they involve committed participants who are willing to devote time and energy to these projects. The programmes also require creative and flexible planning, where each of the collaborating organisation's values, goals and organisational cultures are acknowledged. Such collaborations also need to have a solid infrastructure in place, and this is often provided by local schools. Likewise, they call for a range of resources and these are often provided by local councils, sponsors or community organisations. Programmes such as those featured in this paper are also characteristically rooted in a sense of local identity and feature a shared sense of leadership and communal ownership. This enables these programmes to develop a strong and sustainable relationship with their broader communities (for further details see the Sound Links final report: Bartleet et al., 2009).

Thinking about these issues more broadly, the benefits to both school music programmes and community music programmes can be substantial. For instance, such collaborations can provide school music programmes with a wide range of learning experiences outside those offered in the formal curriculum. Likewise, music educators working in schools can offer specialised models of instruction to community music programmes. These exchanges can result in a pooling of resources, an enriching musical experience for the participants, and a significant community-building exercise for all involved. Such sentiments are echoed by the Ministerial Council on Education, Employment, Training and Youth Affairs (2007) in the Education and the Arts Statement which recognises these benefits: 'creating partnerships strengthens community identity and local cultures' and 'connecting schools with the arts and cultural sector enriches learning outcomes' (p. 5).

Similar benefits have been documented in the literature more widely. Many have described the ways in such school-community collaborations have improved the quality

\section{CAMBRIDGE JDURNALS}


of learning in the arts, improved students' overall academic performance, and assisted in the development of effective curricula within schools (see Dreeszen et al., 1999, pp. 3-4). Moreover, some have suggested that the process of building such connections can acknowledge and build on the diverse ways that young people actually engage with music-making. As Temmerman (2005) argues, 'music plays an important role in young people's lives and ... school, home and out-of-school musical experiences all contribute in important, differing ways' (pp. 118-119). In line with Temmerman's argument, this paper has shown that building these connections can provide a compelling antidote to the commonly dislocated ways in which school music and community music currently operate. Such collaborations can lead to creative and rigorous music learning and teaching practices, and provide both school students and community members with rich and enjoyable musical experiences that can extend well beyond the school gate and schooling years.

\section{Acknowledgements}

Sound Links was realised with a research grant under the Linkage scheme of the Australian Research Council (2007-2008). The research team included Professor Huib Schippers, Associate Professor Peter Dunbar-Hall, Dr Richard Letts and Dr Brydie-Leigh Bartleet.

\section{Notes}

1 Over a period of two months my colleague Huib Schippers and I undertook interviews and focus groups with over 16 key facilitators and participants in the event, and a local Indigenous musician, Sarah Patrick (Research Assistant) undertook four focus group interviews with over 26 young people involved in the Stylin' UP workshops. Participants in both sets of interviews and focus groups included school students, school music teachers, Stylin' UP facilitators, participants, event organisers, youth workers and local council workers. I visited a number of the workshop sites, including Elorac Place (a community centre), Glenala High School, the Murri School (a local Indigenous school) and the youthbased organisations Inala Wangarra (an Indigenous Youth organisation), CONTACT Inc. (a youthbased community arts organisation for Indigenous, Polynesian, refugee and migrant communities) and Speakout (a not-for-profit youth-based community arts organisation).

2 Over a five-day period, Peter Dunbar-Hall and I undertook 32 interviews and focus groups with over 80 participants. These participants included primary school students, secondary school students, school music teachers, principals, community music facilitators, community music participants, church musicians, instrument repairers, parents, festival organisers, local council workers, a local radio station presenter and a national $\mathrm{ABC}$ Classic FM radio presenter. We attended rehearsals of the Nobodies Drumming Group, the Southern District Pipes and Drums, the NEETO (Never Ever Ever Too Old) Orchestra, the Coast and Vines Club (beginner concert band), a session of the McLaren Vale Folk Club, and joint rehearsals of the community orchestra, Sisters of Abundance Choir, Men's Choir and Children's Choir. We also attended the Tatchilla Community Carols performance, and a performance of the Willunga Youth Orchestra, as well as a service at the local Lutheran Church (which involves many young musicians), and I attended a Community Carols Concert with the Onkaparinga Band at the local hospital. We visited Waverley House (the home of STARS, an arts support group), the Academy of Rock, Tatachilla Lutheran College, McLaren Vale Primary School, a youth drop-in community centre in Aldinga called the VOLT (where ad hoc guitar lessons and jamming occur), Pirramirra winery (which hosts music events, ABC broadcasts and Co-Opera), and attended the launch of Peter Tichner's folk music oral history documentary. 
3 Over a five-day period I undertook 30 interviews and focus groups with over 60 participants. These participants included primary school students, secondary school students, school music teachers, principals, community music facilitators, DRMC participants, parents and local council workers. All of these participants are involved with the DRMC. I attended rehearsals of the Ranges Young Strings, the Dandenong Ranges Orchestra, the Attitude music therapy programme, the Hilltop Singers, and the Dr Swing Show Band, and a DRMC Board Meeting. I observed singing and didgeridoo lessons with Upwey High School students at the DRMC, and travelled out to Ferny Creek Primary School and Monbulk Primary School (both heavily involved in a number of DRMC projects). I also visited the Shire of the Yarra Ranges Council offices to meet with local council workers responsible for community cultural development in the region.

\section{References}

ALBRECHT, G. L. (1997) The changing roles of parents, teachers and community residents in school culture: expanding the context of influence. Dialogue in Instrumental Music Education, 21(1), 1-16.

AMIT, V. (2000) Constructing the Field: Ethnographic Fieldwork in the Contemporary World. London: Routledge.

AUSTRALIA COUNCIL (2001) Planning for the Future: Issues, Trends and Opportunities for the Arts in Australia. Surrey Hills, NSW: Australia Council.

BARTLEET, B. L., DUNBAR-HALL, P., LETTS, R. \& SCHIPPERS, H. (2009) Sound Links: Community Music in Australia. Brisbane: Queensland Conservatorium Research Centre.

BEHAR, R. (1999) Ethnography: cherishing our second-fiddle genre. Journal of Contemporary Ethnography, 28(5), 472-484.

BEHAR, R. (1996) The Vulnerable Observer: Anthropology that Breaks Your Heart. Boston: Beacon Press.

BREEN, M. (1994) Constructing the popular from public funding of community music: Notes from Australia. Popular Music, 13(3), 313-326.

CAHILL, A. (1998) The Community Music Handbook: A Practical Guide to Developing Music Projects and Organizations. Sydney: Currency Press, in association with the Music Council of Australia.

CARRUTHERS, G. (2005) Community music and the 'musical community': beyond conventional synergies. International Journal of Community Music, 3. Retrieved from http://www.intljcm.com/index.html

COFFMAN, D. D. (2006) Voices of experience: interviews of adult community band members in Launceston, Tasmania, Australia. International Journal of Community Music [Electronic Version], D. Retrieved from http://www.intljcm.com/index.html.

COTTRELL, S. (2004) Professional Music-Making in London: Ethnography and Experience. Aldershot: Ashgate.

DEPARTMENT OF EDUCATION, SCIENCE \& TRAINING (2005) Report of the National Review of School Music Education. Canberra: Australian Government.

DREESZEN, C., APRILL, A. \& DEASY, R. J. (1999) Learning Partnerships: Improving Learning in Schools with Arts Partners in the Community. Washington: Arts Education Partnership.

ELLIS, C. (2004) The Ethnographic I: A Methodological Novel about Autoethnography. Walnut Creek, CA: AltaMira Press.

HARRISON, G. (1996) Community music in Australia. In M. A. Leglar (Ed.), The Role of Community Music in a Changing World: Proceedings of the International Society for Music Education, 1994 Seminar of the Commission on Community Music Activity (pp. 39-45). Athens, GA: University of Georgia Press.

HAWKINS, G. (1993) From Nimbin to Mardi Gras: Constructing Community Arts. St. Leonards, NSW: Allen \& Unwin.

HEBERT, D. G. (2005) Music Competition, Cooperation and Community: An Ethnography of a Japanese School Band. Seattle, WA: University of Washington.

\section{CAMBRIDGE JDURNALS}


HIGGINS, L. D. (2006) Boundary-walkers: Contexts and Concepts of Community Music. Limerick: University of Limerick.

MINISTERIAL COUNCIL ON EDUCATION, EMPLOYMENT, TRAINING \& YOUTH AFFAIRS (2007) Education and the Arts Statement. Retrieved from http://www.curriculum.edu.au/mceetya/national_ education_and_the_arts_statement,20981.html

MITCHELL, T. (2006) Blackfellas rapping, breaking and writing: a short history of Aboriginal hip hop. Aboriginal History, 30, 124-137.

MYERS, D. (1992) Teaching learners of all ages. Music Educators Journal, 79(4), 23-26.

PRICE, D. (2002) 'A Quiet Revolution': An Overview of Current Community Music Initiatives in the UK. Paper presented at the Community Music Activities Seminar.

ROBINSON, M. (1998) A collaboration model for school and community music education. Arts Education Policy Review, 100(2), 32-39.

SAATCHI \& SAATCHI (2000) Australians and the Arts: What Do the Arts Mean to Australians - Overview. Surrey Hills, NSW: Australia Council.

TEMMERMAN, N. (2005) Children's participation in music: connecting the cultural contexts - an Australian perspective. British Journal of Music Education, 22(2), 113-123.

TEDLOCK, B. (2000) Ethnography and ethnographic representation. In N. K. Denzin \& Y. S. Lincoln (Eds), Handbook of Qualitative Research (2nd edn) (pp. 455-486). Thousand Oaks, CA: Sage.

VEBLEN, K. K. (2003) Principal themes: compelling connections: Community and music making in Canada. Canadian Music Educator, 45 (2), 25-28. 


\section{Appendix 1 Nine Domains of Community Music in Australia}

\begin{tabular}{|c|c|c|c|}
\hline & Infrastructure & Organisation & Visibility/PR \\
\hline 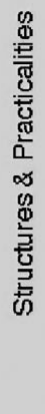 & $\begin{array}{l}\text { - Buildings } \\
\text { - Performance spaces } \\
\text { - Equipment } \\
\text { - Regulations (e.g. } \\
\text { council by-laws) } \\
\text { - Funding } \\
\text { - Earned income } \\
\text { - Legal issues } \\
\text { (e.g. copyright, } \\
\text { insurance, } \\
\text { incorporation) }\end{array}$ & $\begin{array}{l}\text { - Method of organisation } \\
\text { - Inspired leadership } \\
\text { - Structures \& roles } \\
\text { - Division \& delegation of } \\
\text { tasks } \\
\text { - Mentoring of new } \\
\text { leaders } \\
\text { - Membership issues } \\
\text { - Forward planning } \\
\text { - Links to peak \& related } \\
\text { bodies }\end{array}$ & $\begin{array}{l}\text { - Promotion, audience } \\
\text { and membership } \\
\text { development } \\
\text { - Exposure in local press/ } \\
\text { media } \\
\text { - Awards/prizes/ } \\
\text { champions/prestige } \\
\text { - Community centres as } \\
\text { identifiable places }\end{array}$ \\
\hline & Relationship to place & Social engagement & Support/networking \\
\hline 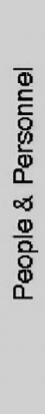 & $\begin{array}{l}\text { - Connections to } \\
\text { location (e.g. urban, } \\
\text { suburban, regional, } \\
\text { rural \& remote) } \\
\text { - Connection to } \\
\text { cultural identity and } \\
\text { cultural heritage } \\
\text { - Pride of place } \\
\text { - Balance between } \\
\text { physical \& virtual } \\
\text { spaces }\end{array}$ & $\begin{array}{l}\text { - Commitment to } \\
\text { inclusiveness (and } \\
\text { sensitivity to issues of } \\
\text { exclusiveness) } \\
\text { - Engaging the } \\
\text { marginalised 'at risk' or } \\
\text { 'lost to music' } \\
\text { - Providing opportunities } \\
\text { - Empowerment } \\
\text { - Links to well-being } \\
\text { - Relationship to audience }\end{array}$ & $\begin{array}{l}\text { - Links to the local } \\
\text { community } \\
\text { - Links to other } \\
\text { community groups } \\
\text { - Links to local council } \\
\text { - Links to business } \\
\text { - Links to local service } \\
\text { providers (e.g. police, } \\
\text { fire \& health) } \\
\text { - Connections to national } \\
\text { peak bodies }\end{array}$ \\
\hline & $\begin{array}{c}\text { Dynamic music- } \\
\text { making }\end{array}$ & $\begin{array}{l}\text { Engaging pedagogy/ } \\
\text { facilitation }\end{array}$ & Links to school \\
\hline 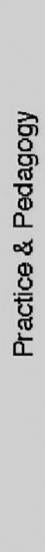 & $\begin{array}{l}\text { - Active involvement } \\
\text { open to all } \\
\text { - Responsive } \\
\text { to ambitions } \\
\text { \& potential of } \\
\text { participants } \\
\text { - Short vs. Iong term } \\
\text { orientation } \\
\text { - Flexible relationship } \\
\text { audience \& } \\
\text { performers } \\
\text { - Balance between } \\
\text { process \& product } \\
\text { - Broad orientation } \\
\text { facilitators }\end{array}$ & $\begin{array}{l}\text { - Sensitivity to differences } \\
\text { in learning styles, } \\
\text { abilities, age \& culture } \\
\text { - Nurturing a sense of } \\
\text { group/individual identity } \\
\text { - Commitment to inclusive } \\
\text { pedagogies (ranging } \\
\text { from formal to informal) } \\
\text { - Embracing multiple } \\
\text { references to quality } \\
\text { - Recognising the need } \\
\text { to balance process \& } \\
\text { product } \\
\text { - Attention to 'training the } \\
\text { trainers' }\end{array}$ & $\begin{array}{l}\text { - Locating activities in } \\
\text { schools } \\
\text { - Identifying mutual } \\
\text { interests } \\
\text { - Sharing of equipment \& } \\
\text { facilities } \\
\text { - Marrying formal \& } \\
\text { informal learning } \\
\text { - Exchange pedagogical } \\
\text { approaches } \\
\text { - Realising activities as } \\
\text { part of the curriculum } \\
\text { - Support \& commitment } \\
\text { from school leadership }\end{array}$ \\
\hline
\end{tabular}

\section{CAMBRIDGE JUURNALS}

